\title{
Behavioral profile and gastrointestinal evaluation of the hydro- alcoholic extract of Sida rhombifolia L. (typychá hû) in mice
}

\author{
O. Y. Heinichen ${ }^{1 *}$, M. C. Hellión-Ibarrola ${ }^{1}$, Y. Montalbetti ${ }^{1}$, A. M. Velázquez ${ }^{1}$, J. H. Dölz-Vargas ${ }^{2}$, D. A. Ibarrola ${ }^{1}$ \\ ${ }^{1}$ Departamento de Farmacología, Facultad de Ciencias Químicas. Universidad Nacional de Asunción. Campus UNA, 1055. San Lorenzo, Paraguay. \\ ${ }^{2}$ Departamento de Farmacología, Facultad de Ciencias, Instituto de Farmacia, Escuela de Química y Farmacia, Universidad Austral de Chile, Valdivia, \\ Chile.
}

\section{ARTICLE INFO}

Article history:

Received on: 16/03/2017

Accepted on: 09/05/2017

Available online: 30/07/2017

\section{Key words:}

Sida rhombifolia; Acute toxicity; Behavior; Intestinal

transit; Intestinal smooth muscle.

\begin{abstract}
The aim of this work was to determine the acute toxicity of hydro-alcoholic extract of S. rhombifolia L. (EHASr), and its influence on general behavior, sleeping time induced by pentobarbital, intestinal transit migration and the effect on spontaneous contractile response of intestinal smooth muscles isolated from mice. Neither oral doses up to $3.000 \mathrm{mg} / \mathrm{kg}$ nor intraperitoneal dose up to $1.000 \mathrm{mg} / \mathrm{kg}$ denoted toxic symptoms, respectively. Oral administration of $100.0 \mathrm{mg} / \mathrm{kg}$ of EHASr promotes statistically significant increase of charcoal marker migration $(* * \mathrm{p}<0.01)$ in the intestinal transit test. By other hand, individual doses of 0.001 , $0.005,0.01$ and $0.05 \mathrm{mg} / \mathrm{mL}$ of EHASr did not modify the spontaneous contractile responses of ileum and jejunum muscles. However, the recovery contractile response of both smooth muscles to ACh $10^{-7} \mathrm{M}$, were increased significantly according to each EHASr pre-treatment The presences of alkaloids, tannins, saponins and steroids and/or triterpenes were detected by qualitative phytochemical assay of EHASr. In conclusion, based on results, oral administration of EHASr is safe, well tolerated and increased the intestinal migration of charcoal marker in mice. This finding is correlated to the popular use of $S$. rhombifolia and encourages us to perform further specific chemical and pharmacological studies.
\end{abstract}

\section{INTRODUCTION}

Typychá hû is the name assigned to at least two species of the Genus Sida (Sida rhombifolia L. and Sida spinosa L.) and indistinctly used in Paraguayan folk medicine for different conditions of the population. Sida rhombifolia L. (Malvaceae) (typychá hû) is a sub-shrub up to $80 \mathrm{~cm}$ with deep, woody and tough roots. It blooms from spring to autumn (Burkert, 2005). It is common in fields, yards and abandoned land (Gatti, 1985). In Argentine the infusion of the leaves of $S$. rhombifolia $\mathrm{L}$ is usually used as a purgative; the tea obtained from the root is indicated as hepatic and the entire plant decoction drunk directly or in gargles is considered effective in case of sore throat (Martinez Crovetto, 1981). In Colombia and Brazil is used for the treatment of

* Corresponding Author

Olga Yolanda Heinichen, Facultad de Ciencias Químicas, Universidad Nacional de Asunción. Campus UNA, 1055. San Lorenzo, Paraguay.

E-mail: olgahena@qui.una.py,Tel: + 59521 585562;

Tel: + 595 971979337; Fax: + 59521585564 kidneys and skin diseases, hemorrhages, toothache, diarrhea, gastritis and useful for fever control (Coelho de Souza, 2004; Harsha, 2003; Barros, 2000). In Mexico, leaves decoction of $S$. rhombifolia is used to cure toothache, diarrhea, gastritis, hemorrhages, fever. Also, the whole plant is used to treat wounds healing. The fruits are used to relieve stomach ulcers and gastritis (Vibrans, 2010).

In Paraguay, the decoction of leaves is used as a diuretic and for vaginal lavages. Also, is used in external friction for rheumatism, gout, arthritis, lumbago, sciatica and muscular pains (González Torres, 2012). Besides, according to Gatti (1985) it is used as a laxative and decongestant of mucous membranes. The $5 \%$ decoction is used in gargles and enemas. The $2 \%$ infusion is drunk as an expectorant and in larger doses is used as a laxative. Cataplasms are prepared from the leaves. In the Central Chaco the root is used for pains of kidneys and wounds healing (Polini, 2013). Sida spinosa L. is reported as medicinal and is used as an antiseptic, stomach and diuretic in Paraguay (Pin et al., 2009). 
The root decoction is used as antidiarrheal and diuretic (Vera, 2009). The root and leaves for stomach pain and muscle aches in the legs (Polini, 2013). Some of the secondary metabolites that have been isolated from $S$. rhombifolia L. are pseudoephedrine, beta-phenyl ethylamine, ephedrine, vascine and vascinol. In addition, beta-sitosterol and other compounds derived from choline have been reported. The presence of hypoforine and indole alkaloids has been reported in the stem (Duke, 1999; Dinan, 2001). Recently, Souza Chaves et al., (2017) using chromatographic and spectroscopic techniques, have identified eight substances (Scopoletin, escoporone, ethoxy-ferulato, kaempferol, kaemferol-3-O-D-glycosil-6" -D-rhamnose, quindolinone, 11-methoxy-quindoline and quindoline). $\mathrm{A}$ vasorelaxation dependent on intact vascular endothelium were provoked by quindoline and cryptolepine salt, and have been correlated with the use of the species in India folk medicine. (Souza Chaves et al., 2017). Antibacterial (Goyal, 1988), cytotoxic (Islam, 2003) and anti-inflammatory activities were reported (Khalil et al., 2006). Also, anti-inflammatory, anti-cholinesterase and cytotoxic effects of $S$. rhombifolia were mentioned recently (Mah et al., 2017). Besides, S. rhombifolia has the potential effect to alleviate the conditions of moderate diabetic, but not in severe diabetes induced by alloxan in rats (Chaturvedi and Kwape, 2015). Paraguayan society has a deep cultural credibility and adherence to the use of medicinal plants as medical purpose. The significance of this study is linked to increase an information profile about pharmacological activity of this natural resource. Indeed, pharmaco-toxicological information on Paraguayan medicinal plants are scarce on literature, for instance this is a nice opportunity to generate a new knowledge with high potential impact in strengthening academic, health, commercial and social life style. The cultivation of medicinal plants of proven effectiveness could eventually represent an interesting economic activity to be implemented, since the development of phytopharmaceuticals will be sustainable with adequate cultivation techniques and not the simple collection of wild species that would only collaborate to the predation and disappearance of native and useful species. This study proposes to evaluate the acute toxicity, the influence on the sleep time induced by pentobarbital, the effects on the central nervous system and the influence on the gastrointestinal motility (In Vivo or in vitro) under administration of the crude hydro-alcoholic extract of Sida rhombifolia L. in mice

\section{MATERIALS AND METHODS}

\section{Plant material and extract preparation}

Sida rhombifolia L. (Malvaceae) named typychá hû in guarani, was collected in rural area of Villeta (Southern Access, Central Department), on September 7, 2012. The plant material was identified by members of the Departamento de Botanica at the Facultad de Ciencias Químicas and a voucher sample was deposited under the code N. Soria $N^{\circ} 8097$. The fresh whole plant collected was dried at room temperature, cut into small pieces and reduced to fine powder by milling. The extract was prepared by refluxing $430 \mathrm{~g}$ of powder with a 70:30 ethanol: water mixture, in a water bath at $80{ }^{\circ} \mathrm{C}$ for one hour with shaking every 10 minutes. After one hour the extract was filtered through a thin membrane. The remaining extractive plant material was subjected to a second extraction with equal volume of solvent in identical conditions. The filtrates were collected and homogenized in the same flask and then concentrated by evaporation under reduced pressure on a rotary evaporator. The residue was then frozen and lyophilized yielding $51.6 \mathrm{~g}$ of lyophilized powder extract of EHASr with an approximate yield of $12 \%$. The resulting powder was stored in a desiccator at room temperature and protected from light and the chemical and biological identification tests were performed with the material thus obtained.

\section{Animals}

Swiss albino mice of both sexes weighing 20-30 g were obtained from the Bioterium of the Facultad de Ciencias Químicas (UNA). Animals were used to determine the pharmacotoxicological influence of the hydro-alcoholic extract of $S$. rhombifolia (EHASr) on In Vivo (acute toxicity, influence on general behavior, hole board, barbiturate-induced sleeping time and gastrointestinal migration of charcoal administered orally) and in vitro (contractile response of ileum and jejunum) preparations. The animals were kept in a room with controlled temperature (23$\left.25^{\circ} \mathrm{C}\right)$, humidity environment $(50-60 \%)$ and light/dark cycle of $12 \mathrm{~h}$ (cycle starting from 06:00 a.m. to 6:00 p.m.) with free access to water and food. The experimental procedures performed in the present work were conducted in agreement with international standards of animal welfare and the protocol was previously approved by the Bioethical Committee of Facultad de Ciencias Químicas (code protocol PI-03/12). The experimental procedure was designed in order to minimize actions involving stress or discomfort to animals during experiments. The number of animals used per experimental group was the minimum for obtaining data's for reliable statistical analyzes. The experiments were performed from 9:00 a.m. to 2:00 p.m., and the animals were fasted overnight with drinking water ad libitum.

\section{Drugs (Reagents And Drugs)}

All reagents used were of analytical grade. Sodium chloride, potassium chloride, calcium chloride and magnesium chloride were obtained from Wako Pure Medical Industries Ltd (Japan). Sodium bicarbonate and D (+) - anhydro-glucose from Merck (Darmstadt, Germany); dihydrogen phosphate sodium from Riedel-de Haen AG (Seelze, Germany). Sodium pentobarbital (Nembutal Abbott, Japan); Diazepam (Valium Roche Laboratory, Argentina); acetylcholine from Sigma Chemical Company (St. Louis, MO, USA); atropine, neostigmine, ethanol and activated charcoal for pharmaceutical use were purchased locally .

\section{Phytochemical Analysis}

The EHASr was examined using the standard methodology described by Sanabria Galindo (1983). Basically it consists of a sequence of colorings and/or precipitation reactions 
in order to detect major groups of secondary metabolites which may be present in the sample under study.

\section{In Vivo Studies \\ Acute toxicity}

The fixed-dose procedure (FDP) with small modifications proposed by the British Society of Toxicology (1984) was used as an alternative method of refinement and reduction in the use of laboratory animals and currently included in the OECD Guidelines (Organization for Economic Cooperation and Development). A pilot trial, starting at the maximum dose level and using a single mouse, was performed in order to visualize symptoms or toxic effects induced by dose of EHASr used. According to the appearance of symptoms or toxic effects the dose should be decrease gradually until achieving the dose where no symptoms or toxic effects of EHASr can be detected. The main study was performed sequentially with groups of 5 mice/doses (Swiss albino of both sexes) weighing 20-30 g and observed during $24 \mathrm{~h}$. The extract samples were suspended in distilled water and administered orally, using syringes provided with gastro-esophageal cannulas at fixed dose levels of 100.0, 1000.0, 2000.0 and $3000.0 \mathrm{mg} / \mathrm{kg}$. Different groups of mice were administered by intraperitoneal route with 100.0, 500.0 and 1000.0 $\mathrm{mg} / \mathrm{kg}$ respectively. After $24 \mathrm{~h}$ of visual acute assessment, the observation periods was prolonged up to 14 days so as to detect the occurrence of delayed or sub-acute toxic effects in animals surviving the treatment according to the FDP method (Stallard and Whitehead, 2004). After 14 days of observation mice were euthanized. The internal organs were examined macroscopically and compared according to corresponding treatments against the control group treated with the vehicle (OECD, 2008).

\section{The gross behavior test}

The Hippocratic procedure (Malone, 1977) was used for the evaluation of the influence of EHASr on the spontaneous behavior of mice. Five groups of eight adult albino mice (both sexes) were orally treated with distilled water $(0.1 \mathrm{~mL} / 10 \mathrm{~g}$ body weight) and doses of 1.0, 10.0, 100.0 and $1000.0 \mathrm{mg} / \mathrm{kg}$ of EHASr, respectively. After administration, each animal was observed individually during 5 minutes at 15 minute intervals within a total period of $4 \mathrm{~h}$. All mice were kept continuously under brief daily observation for seven days. The behavioral profile of albino mice under treatments was registered individually placing the animals inside the observation cage. The modifications of the humor, the conscience, the motor activity and the autonomic activity by simple and direct observation were registered cataloguing $(0-4+)$ as central or peripheral behaviors (Irwin, 1964).

\section{Hole-board test}

A plexiglas hole-board apparatus of $15 \mathrm{~cm}$ of height, 40 $\mathrm{cm}$ of length and $40 \mathrm{~cm}$ of width was used. A black floor marked with white lines limiting areas of $10 \mathrm{~cm}^{2}$ with a hole $(2.0 \mathrm{~cm}$ of diameter) in the center (total of 16 holes $/ 1600 \mathrm{~cm}^{2}$ ) were arranged in the arena. Mice were randomly assigned to six groups (6 animals each) and the first group was treated orally with saline solution $(0.1 \mathrm{~mL} / 10 \mathrm{~g}$ body weight $)$ and considered as a control. A second group was injected with diazepam $(0.5 \mathrm{mg} / \mathrm{kg}$, i.p. $)$. Others four groups were treated orally with 10.0, 100.0, 500.0 and 1000.0 $\mathrm{mg} / \mathrm{kg}$, of EHASr. One hour after treatments each mouse was individually placed in the center of the arena and defecation, ambulation (peripheral and central zone) and rearing of animals during 5 minutes were registered by direct observation (File \& Pellow, 1985; De Lima, 2002).

\section{Rota-rod test}

A 12-rpm rotating rod $(2.5 \mathrm{~cm}$ diameter $)$ divided in six equal compartments was used. Twenty four hours before experiment, two successive trials ( $2 \mathrm{~min} / \mathrm{each}$ ) were performed and those animals remaining on spinning rod were selected and randomly assigned to six different experimental groups $(\mathrm{n}=$ 6/each). One group was treated with vehicle $(0.1 \mathrm{~mL} / 10 \mathrm{~g}$ body weight p.o) and considered as a control. A second group was injected with diazepam $(0.5 \mathrm{mg} / \mathrm{kg}$, i.p. $)$. Besides, four groups were treated orally with $10.0,100.0,500.0$ and $1000.0 \mathrm{mg} / \mathrm{kg}$, of EHASr. Sixty minutes after each treatment, according to individual timing, mice were placed on the spinning bar apparatus for 1 minutes and time (s) spent on was recorded (Duham and Myia, 1957; De Lima, 2002).

\section{Pentobarbital-induced hypnosis}

Male mice (20-30 g) were randomly allocated in six groups of ten animals per dose and sixty minutes after oral administration of saline $(0.1 \mathrm{~mL} / 10 \mathrm{~g}$ body weight), EHASr $(10.0$, $100.0,500.0$ and $1000.0 \mathrm{mg} / \mathrm{kg}$ ), each animal was injected with sodium pentobarbital (40 mg/kg, i.p.). Group receiving diazepam $(0.5 \mathrm{mg} / \mathrm{kg}$ i.p.) was treated 20 minutes later with pentobarbital (40 $\mathrm{mg} / \mathrm{kg}$, i.p.) and considered as positive control (standard hypnosedative drug) in this assay. Induction time in seconds and sleeping time in min were registered for each animal (Carlini, 1986; De Lima, 2002).

\section{Gastrointestinal transit in mice}

Groups of 15 female mice fasted 16 hours with free access to water were randomly allocated in seven different groups. One group was treated orally with $0.3 \mathrm{~mL}$ vehicle $(0.1 \mathrm{~mL} / 10 \mathrm{~g}$ body weight) as a control. Another two groups were treated with, neostigmine methyl sulfate $(10.0 \mu \mathrm{g} / \mathrm{kg}$ s.c. $)$ and atropine sulfate (1.0 mg/kg i.p.) and considered as positive and negative controls, respectively. Additionally, four groups received orally doses of $10.0,100.0,500.0$ and $1000.0 \mathrm{mg} / \mathrm{kg}$ of EHASr, separately. A maximal volume of $0.1 \mathrm{~mL} / 10 \mathrm{~g}$ body weight was used for oral administration of all samples. One hour after treatments, $0.3 \mathrm{~mL}$ of charcoal suspension (10\%) was administered orally, according to individual timing, to all animals. After 30 minutes, the mice were sacrificed by cervical dislocation; the small intestine was carefully removed and aligned quickly in parallel to a ruler. The total intestinal length (from the pyloric sphincter to the ileo-coecal junction) and the distance traveled by marker were tabulated and 
managed for calculation of the charcoal migration in percentage of total intestinal extent (Williamson, 1996; Soucccar, 2002).

\section{In Vitro Studies}

\section{Spontaneous contractile response of ileum muscle isolated from} mice

Adult albino mice of both sexes (20-30 g) were sacrificed by cervical dislocation. The abdomen was opened and about $20 \mathrm{~cm}$ of ileum portion was transferred to a Petri dish filled with Tyrode's solution. The mM composition of Tyrode's solution used was $\mathrm{NaCl} 135.0 ; \mathrm{KCl} 5.0 ; \mathrm{CaCl}_{2} 2.0 ; \mathrm{MgCl}_{2}$ 1.0; $\mathrm{NaHCO}_{3}$ 15; $\mathrm{NaH}_{2} \mathrm{PO}_{4} 1.0$; Glucose 11 with final $\mathrm{pH}$ of $7.4 \pm 0.2$. A $1.0 \mathrm{~cm}$ length of ileum segment was mounted in a $10 \mathrm{~mL}$ organ bath containing Tyrode's solution bubbled continuously with air pump and the temperature was held at $30^{\circ} \mathrm{C}$. Spontaneous contractions were registered through a front writing lever in a kymograph, and preparation was submitted to $0.5 \mathrm{~g}$ of load. Prior to drugs addition a periodic washing were performed every 10 minutes and the preparation was allowed to stabilize for approximately 30 minutes. Then the preparation was stimulated with $10^{-7} \mathrm{M}$ Acetylcholine solution and washed with fresh Tyrode's solution after maximal response was reached.

The most representative response from 2 to 3 stimulations with $10^{-7} \mathrm{M}$ Acetylcholine was considered as control response and all contractile responses obtained with $0.001 ; 0.005$; 0.01 and $0.05 \mathrm{mg} / \mathrm{mL}$ of EHASr was used to compare with (Van Rossum, 1963).

\section{Spontaneous contractile response of jejunum muscle isolated from mice}

Adults albino mice of both sexes (20-30 g) were sacrificed by cervical dislocation. The abdomen was opened and about $20 \mathrm{~cm}$ of jejunum portion was transferred to a Petri dish filled with Tyrode's whose composition was mentioned above. A $1.0 \mathrm{~cm}$ length of jejunum segment was mounted in a $10 \mathrm{~mL}$ organ bath containing Tyrode's solution, continuously bubbled with air pump and the temperature was held at $30^{\circ} \mathrm{C}$. Spontaneous contractions were registered through a front writing lever in a kymograph, and preparation was submitted to $0.5 \mathrm{~g}$ of load. Prior to drugs addition a periodic washing was performed every 10 minutes and the preparation was allowed to stabilize for approximately 30 minutes. Then the preparation was stimulated with $10^{-7} \mathrm{M}$ Acetylcholine solution and washed with fresh Tyrode's solution after maximal response was reached. The most representative response from 2 to 3 stimulations with $10^{-7} \mathrm{M}$ Acetylcholine was considered as control response and all contractile responses obtained with $0.001 ; 0.005 ; 0.01$ and 0.05 $\mathrm{mg} / \mathrm{mL}$ of EHASr was used to compare with (Van Rossum, 1963).

\section{Statistical Analysis}

A statistical analysis of the data was carry out by oneway analysis of variance (ANOVA) followed by Dunnet's multiple comparison tests. GraphPad Prism 5.0 software (GraphPad
Software, Inc. CA. USA) was utilized and results were expressed as mean \pm S.D. Differences were considered to be statistically significant when $p$ level was less than 0.05 .

\section{RESULTS}

\section{Phytochemical analysis}

Preliminary analysis of EHASr denoted the presence of alkaloids, tannins, saponins and steroids and/or triterpenes.

\section{Acute toxicity (LD50) and effect on general behavior}

Oral and intraperitoneal administration of EHASr up to $3000.0 \mathrm{mg} / \mathrm{kg}$ and $1000.0 \mathrm{mg} / \mathrm{kg}$, respectively, caused no lethality after 24 hours of observation. After 14 days of observation, mice were sacrificed and internal organs were macroscopically evaluated. According to each treatment, no signs of morphoanatomical alteration of internal organs were observed in comparison to analogous organs in the control group. Oral treatment with doses of $1.0,10.0,100.0$ and $1000.0 \mathrm{mg} / \mathrm{kg}$ of EHASr provoke no significant effects on the general behavior of mice. Dose dependent piloerection and abdominal writhing were observed in mice treated (i.p) with 1.0, 10.0, 100.0 and 1000.0 $\mathrm{mg} / \mathrm{kg}$ of EHASr. However, these properties are not relevant because no purified material is used, are non-specific and shortterm duration effects and the intensity diminished to total disappearance.

\section{Effect of oral administration of EHASr on mice performance in hole-board and rota rod test}

Oral administration of $10.0,100.0$ and $1000.0 \mathrm{mg} / \mathrm{kg}$ EHASr did not provoke difference in ambulatory (total, peripheral and central area), emotional (rearing, grooming and defecation) and in percentage of head dipping in comparison to the control group (Figure 1, 2 and 3).

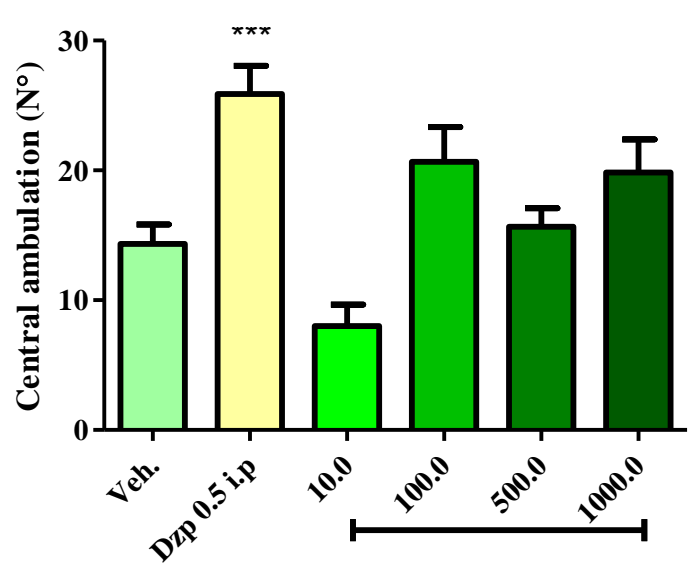

Treatments (EHASr mg/kg p.o)

Fig. 1: Effect of oral administration of vehicle $(0.1 \mathrm{~mL} / 10 \mathrm{~g}$ body weight), $10.0,100.0,500.0$ and $1000.0 \mathrm{mg} / \mathrm{kg}$ of EHASr on central quadrants ambulation of male mice. The diazepam $(0.5 \mathrm{mg} / \mathrm{kg}$ i.p) was used as positive control of anxiolytic agent. Each bar represents the mean \pm SD of 6 animal's locomotion. * $\mathrm{p}<0.05 ; * * \mathrm{p}<0.01 ; * * * \mathrm{p}<0.001$ significantly different from vehicle. 


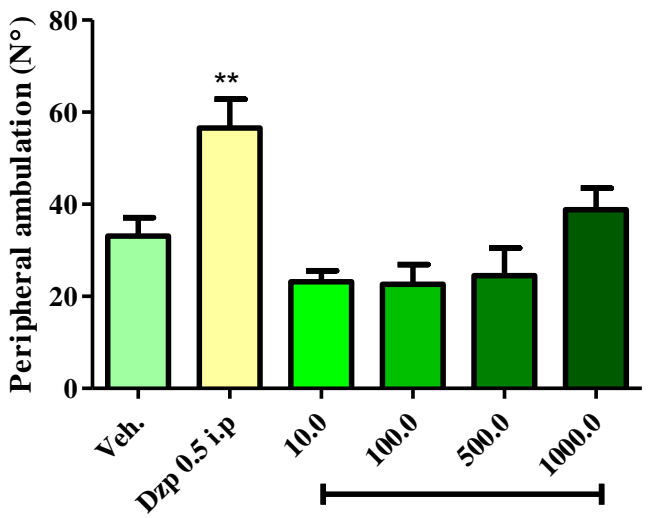

Treatments (EHASr mg/kg p.o)

Fig. 2: Influence of oral administration of vehicle $(0.1 \mathrm{~mL} / 10 \mathrm{~g}$ body weight $)$ $10.0,100.0,500.0$ and $1000.0 \mathrm{mg} / \mathrm{kg}$ of EHASr on peripheral quadrants ambulation of male mice. The Dzp $(0.5 \mathrm{mg} / \mathrm{kg}$ i.p. $)$ was used as positive control of anxiolytic agent. Each bar represents the mean \pm SD of 6 animal's ambulation. $* \mathrm{p}<0.05 ; * * \mathrm{p}<0.01 ; * * * \mathrm{p}<0.001$ significantly different from vehicle.

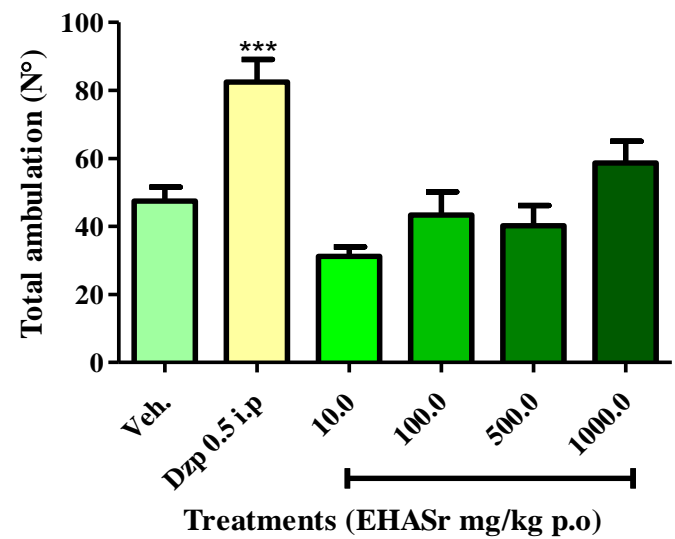

Fig. 3: Influence of oral administration of vehicle $(0.1 \mathrm{~mL} / 10 \mathrm{~g}$ body weight $)$, $10.0,100.0,500.0$ and $1000.0 \mathrm{mg} / \mathrm{kg}$ of EHASr on total quadrants ambulation in male mice. The Dzp $(0.5 \mathrm{mg} / \mathrm{kg}$ i.p $)$ was used as positive control of anxiolytic agent. Each bar represents the mean \pm SD of 6 animal's ambulation. $* \mathrm{p}<0.05 ; * * \mathrm{p}<0.01 ; * * * \mathrm{p}<0.001$ significantly different from vehicle.

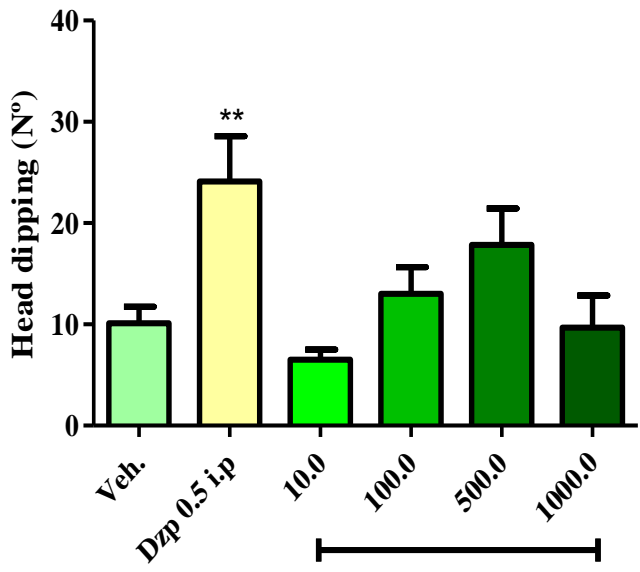

Treatments (EHASr mg/kg p.o)

Fig. 4: Influence of oral administration of vehicle $(0.1 \mathrm{~mL} / 10 \mathrm{~g}$ body weight $)$, $10.0,100.0,500.0$ and $1000.0 \mathrm{mg} / \mathrm{kg}$ of EHASr on the number of head dipping registered in a 5 min session in the hole-board test in male mice. The Dzp $(0.5$ $\mathrm{mg} / \mathrm{kg}$ i.p) was used as positive control of anxiolytic agent. Each bar represents the mean $\pm \mathrm{SD}$ of the number of head-dipping of 6 animals. * ${ }^{*}<0.05 ; * * \mathrm{p}$ $<0.01 ; * * * \mathrm{p}<0.001$ significantly different from vehicle.
DZP in a no sedative dose $(0.5 \mathrm{mg} / \mathrm{kg}$ ip $)$, proved to be an efficient anxiolytic-like agent and induced a no impairment of motor coordination in this test $(\mathrm{p}<0.001)$. However, a dose of 500 $\mathrm{mg} / \mathrm{kg}$ increased the time of head-dipping behaviour in comparison to control group (Figure 4 and 5). In addition, the motor coordination of mice was no modified in the rota-rod test. Dose of $0.5 \mathrm{mg} / \mathrm{kg}$ i.p. of diazepam was used as positive control (data not shown).

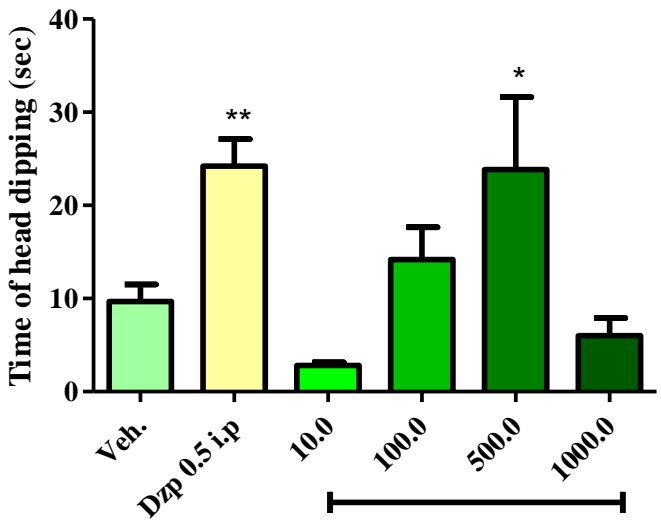

Treatments (EHASr mg/kg p.o)

Fig. 5: Influence of oral administration of vehicle $(0.1 \mathrm{~mL} / 10 \mathrm{~g}$ body weight), $10.0,100.0,500.0$ and $1000.0 \mathrm{mg} / \mathrm{kg}$ of EHASr on duration of head dipping registered in a 5-min session in the hole-board test in male mice. The DZP i.p. $(0.5 \mathrm{mg} / \mathrm{kg})$ was used as positive control of anxiolytic agent. Each bar denotes the mean $\pm \mathrm{SD}$ time head-dipping of 6 animals. ${ }^{*} \mathrm{p}<0.05 ; * * \mathrm{p}<0.01$, $* * * \mathrm{p}<0.001$ are statistically different from vehicle.

\section{Effect of oral administration of EHASr on pentobarbital- induced sleep in mice}

The effect of oral administration of 10.0, 100.0, 500.0 and $1000.0 \mathrm{mg} / \mathrm{kg}$ of EHASr did not provoke a statistically significant effect either on the induction (data not shown) or sleep time induced by injection of pentobarbital $40 \mathrm{mg} / \mathrm{kg}$, i.p., in mice (Figure 6).

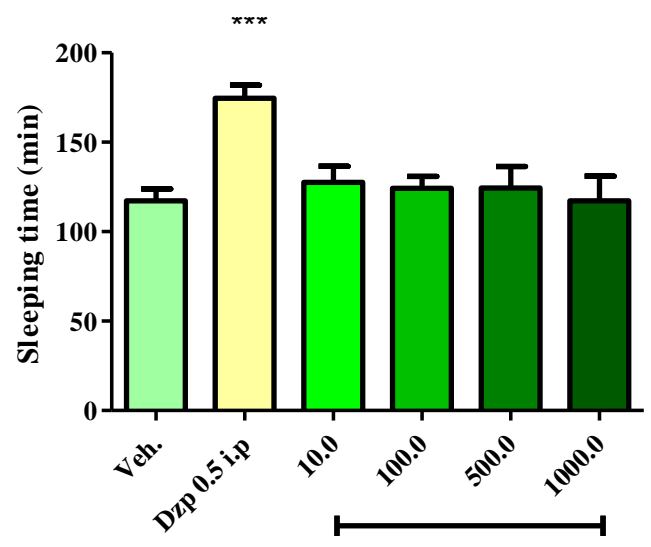

Treatments (EHASr mg/kg p.o)

Fig. 6: Influence of oral administration of vehicle $(0.1 \mathrm{~mL} / 10 \mathrm{~g}$ body weight), $10.0,100.0,500.0$ and $1000.0 \mathrm{mg} / \mathrm{kg}$ of EHASr on hypnosis time induced by sodium pentobarbital ( $40 \mathrm{mg} / \mathrm{kg}$, i.p.), in male mice. Dzp ( $0.5 \mathrm{mg} / \mathrm{kg}$ i.p) was used as positive control of central depressant agent and for validation of the method used. Each bar represents the mean \pm SD of sleep time of 10 animals. ANOVA followed by Dunnett's multiple comparison tests was used as statistical analysis. ${ }^{*} \mathrm{p}<0.05 ; * * \mathrm{p}<0.01$ significantly different from vehicle. 
Effect of oral administration of EHASr on gastrointestinal motility in mice

A significant increase in gastrointestinal migration of charcoal marker was observed after oral administration of 100 $\mathrm{mg} / \mathrm{kg}$ of EHSr p.o., in mice $(* * \mathrm{p}<0.01)$ in comparison to the control group (Figure 7). This result, suggest the possible presence of a principle(s) with prokinetic activity. The effect of neostigmine $10.0 \mu \mathrm{g} / \mathrm{kg}$ s.c. (positive control) induced an increase migration of marker (***p <0.001) and atropine $1.0 \mathrm{mg} / \mathrm{kg}$ i.p. (negative control) provoked a significant decrease migration of charcoal $(* * \mathrm{p}<0.01)$ validating the method used.

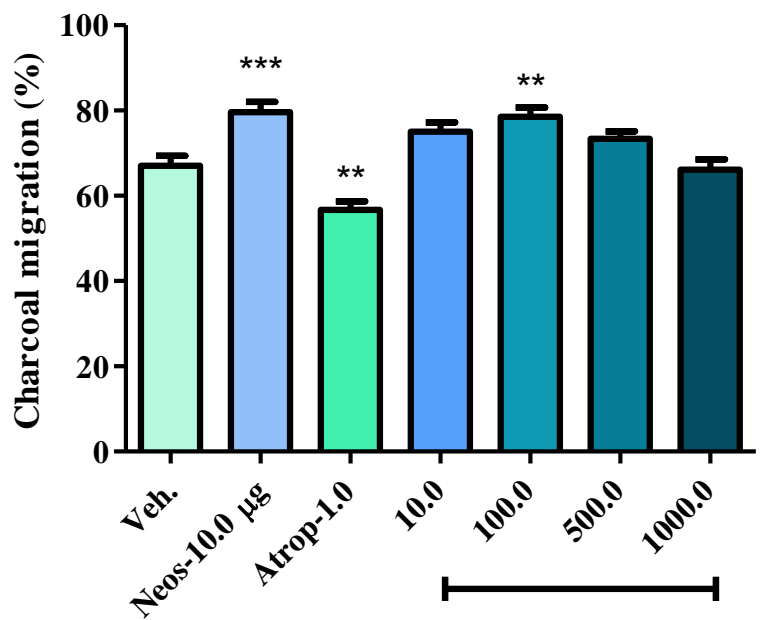

Treatments (EHASr mg/kg p.o)

Fig. 7: Effect of oral administration of vehicle, 10.0, 100.0, 500.0 and 1000.0 $\mathrm{mg} / \mathrm{kg}$ of EHASr; neostigmine $10.0 \mu \mathrm{g} / \mathrm{kg}$ s.c. (positive control) and atropine $1.0 \mathrm{mg} / \mathrm{kg}$ i.p. (negative control), on intestinal transit of different groups of female mice $\left(\mathrm{n}_{=} 15\right)$. Each bar represents the mean \pm SD percentage of net charcoal migration administered $30 \mathrm{~min}$ after the treatments mentioned above. $* \mathrm{p}<0.05 ; * * \mathrm{p}<0.01 ; * * * \mathrm{p}<0.001$ significantly different from vehicle.

\section{Effect of EHASr on the spontaneous contractile activity of ileum and jejunum muscles isolated from mice.}

Individual addition of EHASr in concentrations of 0.001 , $0.005,0.01$ and $0.05 \mathrm{mg} / \mathrm{mL}$ did not modify the spontaneous contractile response of ileum muscle isolated from mice. However, after washing, the recovery contractile response induced by $\mathrm{ACh}$ $10^{-7} \mathrm{M}$, was significantly superior in comparison to control response obtained before extract application. Certainly, the recovery contractile response of ileum muscles to $\mathrm{ACh} 10^{-7} \mathrm{M}$ were increased significantly according to each EHASr pre-treatment $(0.005 \mathrm{mg} / \mathrm{mL}, \mathrm{p}<0.05 ; 0.01 \mathrm{mg} / \mathrm{mL}, \mathrm{p}<0.05$ and $0.05 \mathrm{mg} / \mathrm{mL}$, ** $\mathrm{p}<0.01)$. The mechanism of this effect is unknown; however, shows that pretreatment with EHASr enhance ACh-induced ileum contraction and could be due to the presence of active (s) metabolite (s) sensitizers of muscarinic mechanisms or linked to them (Figure 8). Indeed, this effect needs extensive study to become an effective complementary test to follow the previous pro- kinetic activity. Besides, this finding strengthens the popular use of this natural resource as a digestive.

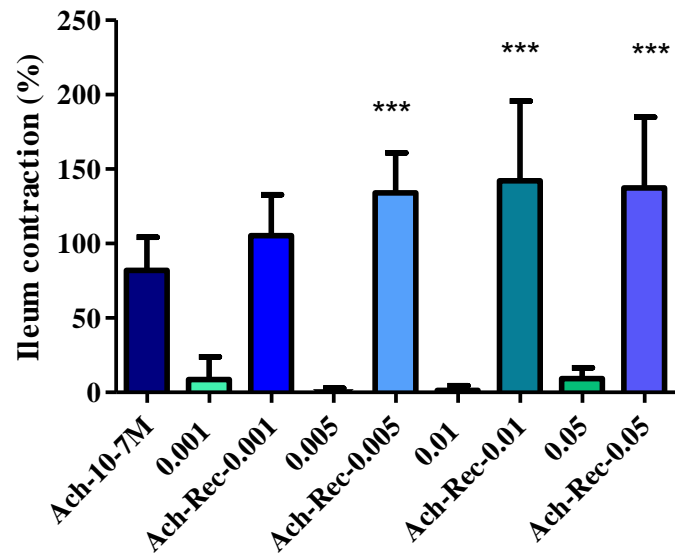

Concentration of EHASr $(\mathrm{mg} / \mathrm{mL})$

Fig. 8: Effect of single dose administration of $0.001,0.005,0.01$ and 0.05 $\mathrm{mg} / \mathrm{mL}$ of EHASr on spontaneous contractile response and a recovery control response induced Ach $10^{-7} \mathrm{M}$ in ileum muscle isolated from mice. The contractile response to Ach $10^{-7} \mathrm{M}$ (after washing with Tyrode's solution) of ileum treated with single dose of 0.005 (Ach-Rec-0.005), 0.01 (Ach-Rec-0.01) and 0.05 (Ach-Rec-0.05) $\mathrm{mg} / \mathrm{mL}$ respectively showed a statistically significant potentiation of the contractile response to muscarinic agent. The Ach $10^{-7} \mathrm{M}$ was added once stabilized after thorough rinsing of the preparations. Each bar represents the mean \pm SD of percentage of contraction of the ileum of nine animals. * $\mathrm{p}<0.05 ; * * \mathrm{p}<0.01 ; * * * \mathrm{p}<0.001$ significantly different from contraction induced by control Ach $10^{-7} \mathrm{M}$

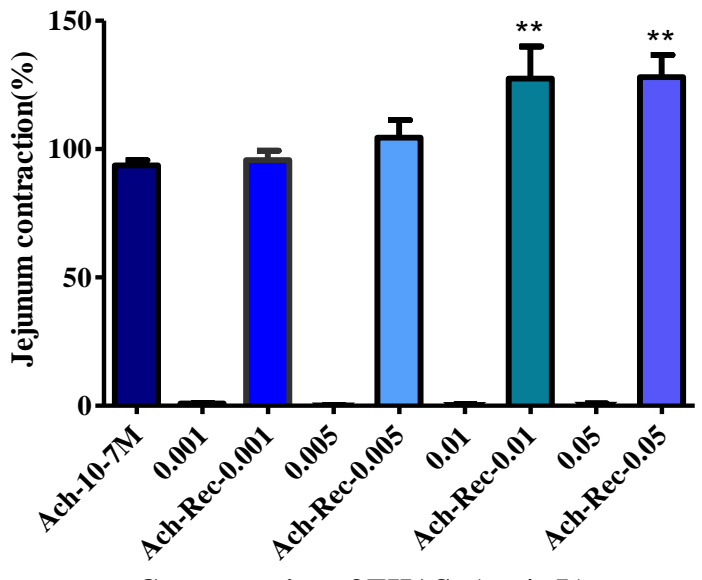

Concentration of EHASr $(\mathrm{mg} / \mathrm{mL})$

Fig. 9: Effect of single dose administration of $0.001,0.005,0.01$ and 0.05 $\mathrm{mg} / \mathrm{mL}$ of EHASr on spontaneous contractile response and a recovery control response induced by Ach $10^{-7} \mathrm{M}$ in jejunum muscle isolated from mice. The contractile response to Ach $10^{-7} \mathrm{M}$ (after washing with Tyrode's solution) of jejunum treated with single dose of 0.005 (Ach-Rec-0.005), 0.01 (Ach-Rec0.01 ) and 0.05 (Ach-Rec-0.05) $\mathrm{mg} / \mathrm{mL}$ respectively showed a statistically significant potentiation of the contractile response to muscarinic agent. The Ach $10^{-7} \mathrm{M}$ was added once stabilized after thorough rinsing of the preparations. Each bar represents the mean \pm SD of percentage of contraction of the jejunum of nine animals. * $\mathrm{p}<0.05$; ** $\mathrm{p}<0.01 ; * * * \mathrm{p}<0.001$ significantly different from contraction induced by control Ach $10^{-7} \mathrm{M}$.

Moreover, the contractile response of isolated jejunum muscle was similar to ileum by adding doses of $0.001,0.005,0.01$ and $0.05 \mathrm{mg} / \mathrm{mL}$ of EHASr. Surely, the recovery contractile response of jejunum muscles to $\mathrm{ACh} 10^{-7} \mathrm{M}$ were increased significantly according to each EHASr pre-treatment $(0.01$ $\mathrm{mg} / \mathrm{mL}$, ** $\mathrm{p}<0.01$ and $0.05 \mathrm{mg} / \mathrm{mL}$, ** $\mathrm{p}<0.01)$. Therefore, the response profile in intestinal smooth muscle (ileum and jejunum) 
is similar and warrants further studies to elucidate the possible mechanisms of the increase contractile responses induced by ACh $10^{-7} \mathrm{M}$ after EHASr treatments (Figure 9).

\section{DISCUSSION AND CONCLUSIONS}

The results of this study show that the hydro-alcoholic extract of Sida rhombifolia L. (EHASr) reflect an insignificant toxicity, evidenced by both the high values of LD50 (oral and intraperitoneal) and the lack of toxic symptoms in male and female mice. Also, a null behavioral effect was observed after oral and intraperitoneal administration of several doses of EHASr. As no gender-related death or non-fatal toxicity was perceived, an increased chance of receiving innocuous agent is supported (Stallard et al., 2010). All animals fully recovered after 24 hours of observation periods, allusive for a possibly safe natural product and could have a weak potential for adverse events occurrence, confirming a possible harmless use by human population. In addition, motor coordination is one of the physiological parameters finely regulated by the central nervous system. Impairment of motor coordination clearly is linked to a loss of the quality of normal behavioral profile of experimental animals. In this context, the rota-rod test is a model used to evaluate peripheral neuromuscular blockade and motor coordination (Dunham and Miya, 1957). Our results denoted that all EHASr treatments (10.0$1000.0 \mathrm{mg} / \mathrm{kg}$ ), unlike diazepam, had no significant effect on motor coordination using rotating rod test.

Sleeping time induced by pentobarbital is a method considered a very sensitive to detect agents with central nervous system depressant or stimulant properties. In this assay, CNS depressant drugs reduce the time to induce sleep (latency) and increase the sleeping time. On the contrary, CNS stimulant drugs do the opposite. (Carlini, 1973; Carlini and Burgos, 1979). Oral administration of EHAS did not provoke changes in the sleep time at any doses used undeserving any depressant or stimulant properties.

In order to improve behavioral findings, the hole-board test as one valuable model for anxiety in rodents was used. In this assay, the decrease/increase in ambulatory, exploratory and emotional behaviors can be reproduced experimentally an anxiety/anxiolytic-like state (Crawley, 1985; Takeda et al., 1998). Our results denoted that $(500 \mathrm{mg} / \mathrm{kg}$ p.o.) an anxiolytic-like effect based on the increase of the time duration of head dipping induced by EHASr ( $500 \mathrm{mg} / \mathrm{kg}$, p.o.). In addition, neither the number of squares crossed nor locomotion behavior were changed statistically by this treatment. Considering the preliminary tendency, the increase of central ambulation, number and time of head dipping truly are correlated with anxiolytic effect and 500 $\mathrm{mg} / \mathrm{kg}$ may be considered as optimum dose for anxiolytic effect. Certainly, this test has many applications; among others as complementary assay for explore anxiogenic/anxiolytic effect of new drug. Actually, we cannot say that the extract has or not anxiolytic effect because a more specific test like elevated plus maze would be performed to elucidate whether has or not the above-mentioned effect. Concerning to ambulatory behavior, in this preliminary study, the increasing tendency is not significant statistically. Indeed, increase of central ambulation and head dipping are correlated with anxiolytic effect, however, a more detailed behavioral assay will be needed to assure results showed in this preliminary stage. The reason behind this activity (equivalent increase in central ambulation at doses of 100 and $1000 \mathrm{mg} / \mathrm{kg}$ p.o.) may rely on the fact that we are using a row material with unidentified components and with unknown activities. Also, probably some chemical component (s) of the extract has opposite effect to another one or has a molecule with a non-dose response effect on ambulatory behavior. Therefore, purification of the crude extract and performing new experimental task will bring some light in behavioral effects of this natural product. This finding deserves complementary study for detailed conclusion about behavioral influence and to determine the impact on gastrointestinal functions.

Intestinal transit speed is one factor that determines the absorption intensity of luminal contents and regulates the bioavailability of orally administered drugs/foods. Usually, timely oral administration of active charcoal, as marker, to rodents is useful to measure the rate of intestinal transit. This experimental model is sensitive to agents that inhibit/stimulate intestinal peristalsis regulated by autonomic nervous system. This is the rationale for using this assay to investigate the influence of natural products on intestinal peristalsis. (Souccar, 2002). Oral administration of EHASr induced a significant increase in intestinal charcoal migration in mice, suggesting the possible presence of compound (s) with pro-kinetic properties in this medicinal plant. Undoubtedly, we can see the dual effects of the row extract. On one side, the increased tendency in charcoal migration using $10-100 \mathrm{mg} / \mathrm{kg}$ of EHASr was detected. In opposition with $500-1000 \mathrm{mg} / \mathrm{kg}$ of EHASr a decreased effect is observed. Consequently, at higher dose, the decrease in migratory effect appeared may be due to the high concentration de compounds that elicit only inhibition of intestinal function; whereas lower doses are more efficient to induce intestinal stimulation. Clearly, bio-guide fractionations with different solvents and purification procedure will separate definitively these observed dual activities. This finding is correlated whit our results but we cannot extrapolate directly because biological entities are very different and required new experimental assessment.

In addition, complementary in vitro assays using isolated intestinal smooth muscle denoted curious pharmacological activity. First, the predominant motor innervation of the intestinal smooth muscle is cholinergic (parasympathetic stimulant), modulated by sympathetic inhibitory activity. The ileum and jejunum have a moderate spontaneous contractions and very sensitive to agents that interfere with cholinergic activity. The advantage of these preparations on other is the rapid stabilization and constancy of the contractile response. Although spontaneous contractile response of the ileum and jejunum were not affected by addition of individual doses of EHASr, the recovery contractile 
response induced ACh recovery $10^{-7} \mathrm{M}$, curiously was increased in approximately more than $50 \%$. This fact shows that pretreatment with EHASr could have sensitized muscarinic mechanisms and thus potentiate the contractile effects $10^{-7} \mathrm{M}$ ACh on intestinal smooth muscle. The mechanisms of In Vivo and in vitro effects observed are unknown. But these effects (In Vivo pro-kinetic and in vitro improvement of smooth muscle contractility) are effective preliminary indicators that correlate and strengthen the popular use of this natural resource as a digestive. However, as in other in vitro assay, extracts is of non-physiological nature and its composition can stimulate nonspecific cellular system that should be analyzed with caution (Souccar, 2002). As this stage, we have not evaluated the mechanism of action because a crude material is used. It will be a next step after a purification of crude extract. Also, at this instance we cannot speculate about active moiety component of the extract. However, Mah, et al., (2017) have mentioned an anticholinesterase effect of n-hexane extract in two lines of human cancer cells (SNU-1 and Hep G2). The presence of compounds with potential cholinesterase inhibition activity, could explain probably the increase of intestinal transit and the potentiation of contractile response of isolated intestinal smooth muscle to $\mathrm{ACH}$ $10^{-7}$ M. Consequently, all In Vivo and in vitro effects observed, deserved further studies to elucidate the possible mechanisms of the contractile responses experimentally induced by EHASr.

In conclusion, based on results the oral administration of hydro-alcoholic extract of $S$. rhombifolia $\mathrm{L}$. is safe, well tolerated and increased the intestinal migration of charcoal marker in mice. This finding is correlated to the popular use of S. rhombifolia and encourages us to perform specific chemical and pharmacological evaluation at gastrointestinal level.

\section{ACKNOWLEDGEMENTS}

This research work was carry out under the financial support of Facultad de Ciencias Químicas de la Universidad Nacional de Asunción. We also want to thank to Departamento de Botánica and Departamento de Fitoquimica from Facultad de Ciencias Químicas for supporting us with identification of plant material and qualitative chemical composition of the extract obtained, respectively.

\section{Conflict of interest}

The authors declare that they have no conflict of interest.

\section{Author contributions}

This research was initiated and developed by OH. MY and VAM were involved in the design of the study and the experimental implementation. MCH-I were involved in evaluating behavioral data's and making a revision of preliminary written manuscript. D-VJH and DAI were involved in coordinating the study and supervising the work and involved in writing the final form of the manuscript. All authors read and approved the final manuscript.

\section{REFERENCES}

Barros E. 2000. Etnobotánica de la Sierra Nevada de Santa Marta. Plantas medicinales de los Arhuacos. $1^{\text {a }}$ edición. Editorial Beca de Investigación Cultural, Fomcuartes, Santa Marta, pp 11-72. Spanish.

Burkert A, Bacigalupo N. 2005. Flora Ilustrada de Entre RíosArgentina. Parte IV Dicotiledóneas Arquiclamídeas. B: Geraniales a Umbelliflorales. Ediciones INTA (Instituto Nacional de Tecnología Agropecuaria). Buenos Aires -Argentina. Spanish.

Carlini EA. 1973. Farmacologia Prática sem Aparelhagens. Sarvier, São Paulo, SP, Brazil, pp. 145-197. Portuguese.

Carlini EA, Burgos V. Screening farmacológico de ansiolíticos: metodología laboratorial e comparação entre diazepam e clorobenzepam. Rev Assoc Bras Psiquiatr. 1979; 1: 25-31. Portuguese.

Carlini EA, Contar JDP, Silva-Fihlo AR, Silveira-Fihlo N G. Frochtengarten, M. L. \& Bueno O.F.A. J. Etnopharmacol., 1986; 17: 37.

Chaturvedi P, Kwape TE. Attenuation of Diabetic Conditions by Sida rhombifolia in Moderately Diabetic Rats and Inability to Produce Similar Effects in Severely Diabetic in Rats. Journal of Pharmacopuncture, 2015; 18 (4): 012-019.

Coelho de Souza, G, Haas A, von Poser G, Schapoval A, Elisabetsky E. Ethnopharmacological studies of antimicrobial remedies in the south of Brazil. Journal of Ethnopharmacology. 2004; 90: 135-143.

Crawley JN. Exploratory behavior models of anxiety in mice. Neurosci Behav Rev. 1985; 9:37-44.

De Lima TCM. Métodos farmacológicos para o estudo da atividade sobre o sistema nervoso central. In: Lapa AJ, Souccar C, LimaLandman MTR, Monteiro de Lima TC, eds., Métodos de Avaliação da Atividade Farmacológica de Plantas Medicinais. Editograf, CYTED/ CNPq: Florianópolis, Brasil. 2002; p.72-80

Dinan L, Bourne P, Whiting P. Phytoecdysteroid profiles in seeds of Sida spp. (Malvaceae). Phytochemical Analysis, 2001; March / April, 12 (2): 110-119.

Dunham NW, Miya TS. A note on a simple apparatus for detecting neurological deficit in rats and mice. J Am Pharm Assoc. 1957; 46:208-10.

Duke J. 1999. Chemicals and their biological activities in Sida rhombifolia L. (Malvaceae) Broomweed, Tea plant. Agricultural Research Service (ARS), United States. Department of Agriculture. Database available from: http://www.ars-grin.gov/duke.

File SE, Pellow S. The effects of triazolobenzodiazepines in two Animal tests of anxiety and in the hole board. Br J Pharmacol, 1985; 86 (3): 729-35.

Gatti C. 1985. Enciclopedia guaraní-castellano de Ciencias Naturales y Conocimientos Paraguayos. Arte Nuevo Editores. $1^{\text {a }}$ Edición. Asunción. Paraguay, pp. 292-293. Spanish González Torres DM. 2012. Catálogo de Plantas Medicinales (y Alimenticias y Útiles) Usadas en el Paraguay. Ed. El País. Asunción. Paraguay; pp.394. Spanish.

Goyal M, Rani K. Effect of natural products isolated from 3 species of Sida in some gram-positive and gram-negative bacteria. J. Indian. Chem Soc. 1988; 65 (1): 74-76.

Harsha VH, Hebbar SS, Shripathi V, Hegde G. R. Ethnomedicobotany of Uttara Kannada District in Karnataka, India/ Plants in treatment of skin diseases. Journal of Ethnopharmacology. 2003; 84: $37-40$.

Vibrans H. (ed.), 2010. Malezas de México: Sida rhombifolia http://www.conabio.gob.mx/malezasdemexico/malvaceae/sida-

rhombifolia/fichas/ficha.htm 06/03/2017

Irwin, S. 1964. Drug screening and evaluation of new compounds in animals. In: Animal and Pharmacologic Techniques in Drug Clinical Evaluation. 1st ed. Nodine, J.H., Siegler, P.E. (Eds.). Chicago: Year Book Medical Publischers Inc. pg.36 54.

Islam ME, Haque ME, Mosaddik MA. Cytotoxicity and antibacterial activity of Sida rhombifolia (Malvaceae) grown in Bangladesh. Phytother Res. 2003; 17(8): 973-5.

Khalil N, Sperotto J, Manfrin M. Anti-inflamatory activity of the hydroalcoholyc extract of leaves of Sida rhombifolia L. (Malvaceae). Acta Bonaerense. 2006; 25 (2): 260-1. 
Mah, SH., Teh SS., and Ee, GC.. Anti-inflammatory, anticholinergic and cytotoxic effects of Sida rhombifolia. Pharmaceutical Biology. 2017; 55(1):920-928. doi: 10.1080/13880209.2017.1285322.

Malone MH. 1977. Pharmacological Approaches to natural product screening and evaluation. In: H. Wagner and P. Wolff (Eds) New Natural Products and Plant Drugs. With Pharmacological, Biological or Therapeutical activity. Springer-Verlag, Berlin, pp. 23-53.

Martinez Crovetto, Raul. 1,981. Plants used in medicine in NW Corrientes. Miscellaneous 69.Ministerio of Culture and Education Foundation Miguel Lillo. Tucuman. Argentina, pp.72-73. Spanish.

OECD. Guidelines for the Testing of Chemicals (425) Acute Oral Toxicity - Up and Down Procedure (UDP). OECD Publishing. Adopted: 3 October 2008; pp 7Pin A, González G, Marin G, Césédes G, Cretton S; Christen P, Roguet D. 2009. Plantas Medicinales del Jardín Botánico de Asunción. Editores: Municipalidad de Asunción, Municipalidad de Ginebra-Suiza y la Asociación Etnobotánica Paraguaya. Editorial AGR Servicios Gráficos. Primera edición, p. 199. Spanish.

Polini G, López A. 2013. Comer del Monte. Plantas Medicinales del Chaco Central. Paraguay. COOPI; pp 164-166. Spanish.

Sanabria-Galindo, A. 1983. Preliminary phytochemical analysis. Methodology and its application in the evaluation of 40 plants of the Compositae family. Faculty of Science, Department of Pharmacy, National University of Colombia. Bogotá. pp 63-80.

Souccar C. Métodos farmacológicos utilizados para o estudo da atividade no trato gastrointestinal. In: Lapa AJ, Souccar C, Lima-Landman MTR, Monteiro de Lima TC, eds., Métodos de Avaliação da Atividade Farmacológica de Plantas Medicinais. Editograf, CYTED/CNPq: Florianópolis, Brasil. 2002; p.28-53.

Souza Chaves, O., Ferreira Teles, YC., Morais de Oliveira Monteiro M., Mendes Junior, LDG., Agra, MF., Braga, VA., Sarmento Silva, TM. and Vanderlei de Souza, MF. 2017. Alkaloids and Phenolic Compounds from Sida rhombifolia L. (Malvaceae) and Vasorelaxant Activity of Two Indoquinoline Alkaloids. Molecules 2017, 22, 94; doi: 10.3390/molecules22010094.
Stallard, N., Whitehead, A. A Statistical Evaluation of the Fixed Dose Procedure. LASA / FRAME. ATLA. 2004, 32(2): 13-21.

Stallard N, Price C, Creton S, Indans I, Guest R, Griffiths D, Edwards P. A new sighting study for the fixed concentration procedure to allow for gender differences. Human and Experimental Toxicology 2010; 30(3): 239-249.

Takeda H, Tsuji M, Matsumiya T. 1998. Changes in headdipping behavior in the hole-board test reflect the anxiogenic and/or anxiolytic state in mice. Eur J Pharmacol 1998; 350:21-9.

Van Rossum, J. M. Accumulative Dose Response Curves. II Technique for the Making of Dose Response Curves in Isolated Organs and the Evaluation of Drug Parameters. Arch. Int. Pharmacodyn. 1963 , 143: 299-330.

Vera Jiménez M. 2009. Plantas Medicinales de tres áreas silvestres protegidas y su zona de influencia en el sureste del Paraguay. Fundación Moisés Bertoni. Paraguay, p. 120.

Williansom, M.S.; Okpako, D.T.; Evans, F.J. 1.996. Selection, Preparation and Pharmacological Evaluation of Plant Material.Volúmen 1. Wiley. New York, U.S.A

\section{How to cite this article:}

Heinichen OY, Hellión-Ibarrola MC, Montalbetti Y, Velázquez, A.M., Dölz-Vargas, J.H. and Ibarrola, D.A., Behavioral profile and gastrointestinal evaluation of the hydro-alcoholic extract of Sida rhombifolia L. (typychá hû) in mice. J App Pharm Sci, 2017; 7 (07): 021-029. 